\title{
Fluktuujący zespół Guillaina-Barré w przebiegu systemowej amyloidozy AL — zwiastun progresji?
}

\section{Fluctuating Guillain-Barré syndrome in AL systemic amyloidosis as a progression indicator?}

\author{
Anna Suska ${ }^{1,2}$, Artur Jurczyszyn ${ }^{1,3}$ \\ ${ }^{1}$ Katedra Hematologii, Uniwersytet Jagielloński, Collegium Medicum w Krakowie \\ ${ }^{2}$ Oddział Obserwacyjno-Internistyczny, Szpital Uniwersytecki w Krakowie \\ ${ }^{3}$ Oddział Kliniczny Hematologii, Szpital Uniwersytecki w Krakowie
}

\section{Streszczenie}

Pierwotna uktadowa amyloidoza tańcuchów lekkich (AL), stanowiqaca 4/5 wszystkich przypadków amyloidoz, może przebiegać w postaci neuropatii. W cześsi przypadków stanowi objaw prodromalny, obecny jeszcze przed dokonaniem rozpoznania lub poprzedzajacy progresje choroby. Typowo w obrazie klinicznym dominuja zaburzenia czucia w dystalnych partiach kończyn. W miare postęu procesu chorobowego możliwe jest wystapienie ostabienia napięcia mieśniowego, a także objawów ze strony uktadu autonomicznego. Możliwe sq również atypowe prezentacje neuropatii obejmujace między innymi asymetryczna poliradikulopatie, porażenie nerwów czaszkowych III, $V i$ VII czy mononeuropatie mnogie. W artykule przedstawiono przypadek 58-letniego pacjenta z rozpoznana amyloidoza AL kappa nerek, szpiku i serca, leczona wedtug schematów VD (bortezomib, deksametazon) $i$ CyBorD (cyklofosfamid, bortezomib, deksametazon) oraz autologicznym przeszczepieniem krwiotwórczych komórek macierzystych (auto-HSCT) poprzedzonym wysokodawkowa chemioterapia, u którego rozwinat sie petnoobjawowy zespót Guillaina-Barré niereagujacy na standardowe postepowanie terapeutyczne (infuzje immunoglobuliny ludzkiej i plazmaferezy). Cięzkie objawy demielinizacji aksonalnej poprzedzity progresje amyloidozy, a stopniowa poprawe stanu neurologicznego uzyskano po podjeciu leczenia przyczynowego - zastosowaniu steroidów $w$ duzych dawkach. Aktualnie pacjent przyjmuje deksametazon w monoterapii - do chwili obecnej bez progresji choroby podstawowej $i$ świeżych zaburzen ze strony uktadu nerwowego. Wobec catoksztattu obrazu klinicznego wydaje sie prawdopodobne, że fluktuujacy zespót Guillaina-Barré stanowit zwiastun postęu amyloidozy.

Słowa kluczowe: amyloidoza AL, neuropatia obwodowa, zespół Guillaina-Barré, kortykosteroidoterapia

Hematologia 2018; 9, 3: 239-244

\section{Abstract}

Primary systemic light-chain amyloidosis (AL) that accounts for 4/5 of all cases can be manifested as a neuropathy. In some cases, neuropathy is a prodromal symptom, present even before the diagnosis or preceding the progression of the disease. Typically, it is symmetrical and 
progressive, involving the sensitive rather than motor function in the distal parts of the extremities. It can be accompanied by the paresis and autonomic dysfunction. Some atypical presentations of amyloid neuropathy are also mentioned in the literature including asymmetric polyradiculopathy, cranial nerve (III, V, VII) palsies or multiple mononeuropathies. We present a case study of a 58-year-old male patient with AL kappa-light chain amyloidosis of the kidneys, bone marrow and heart, treated in frontline with VD (bortezomib, dexamethasone) and CyBorD (cyclophosphamide, bortezomib, dexamethasone) and with high-dose melphalan followed by autologous hematopoietic stem cell transplantation (auto-HSCT), who developed Guillain-Barré syndrome not responding to standard treatment (intravenous immunoglobulin and plasmapheresis). Severe symptoms of axonal demyelination proceeded the progression of amyloidosis. The improvement in neurological status was obtained by high dose intravenous corticosteroid therapy. Currently, the patient receives dexamethasone as monotherapy - until now without both hematological and neurological progression. Considering the overall clinical picture, the fluctuating Guillain-Barré syndrome may be a prodromal symptom of the amyloidosis progression.

\section{Key words: AL amyloidosis, peripheral neuropathy, Guillain-Barré syndrome, corticosteroid therapy}

Hematologia 2018; 9, 3: 239-244

\section{Wprowadzenie}

Amyloidoza łańcuchów lekkich (AL, amyloid light-chain) to najczęściej diagnozowany typ amyloidozy, stanowiący około $4 / 5$ wszystkich rozpoznań [1]. Złogi amyloidu zbudowanego $z$ nieprawidłowych łańcuchów lekkich mogą uszkadzać nerwy obwodowe i autonomiczny układ nerwowy, prowadząc do neuropatii. Neuropatię obwodową stwierdza się w 15-20\% przypadków. Może ona nawet o 4 lata wyprzedzać postawienie diagnozy amyloidozy, będąc formą zespołu paranowotworowego [2], a w części przypadków jest głównym objawem zwiastunowym [3-5]. Możliwe są także atypowe prezentacje neuropatii obejmujące między innymi poliradikulopatię, porażenie nerwów czaszkowych III, V i VII czy mononeuropatie mnogie [6].

Nowe leki stosowane w terapii szpiczaka plazmocytowego i systemowej amyloidozy AL (inhibitory proteasomów [PI, proteasom inhibitors] — głównie bortezomib, leki immunomodulujące [IMiD, immunomodulatory drugs] — przede wszystkim talidomid) również mogą powodować działania niepożądane o charakterze neuropatii - sensorycznej lub polineuropatii. Polineuropatia obwodowa jest najczęściej występującym powikłaniem niehematologicznym indukowanym chemioterapią (CIPN, chemotherapy induced polyneuropathy) [1]. Objawy w postaci drętwienia, pieczenia, często $z$ łagodną niedoczulicą, oraz osłabienia siły mięśniowej kończyn najczęściej występują symetrycznie.
Rzadko w przebiegu amyloidozy i w związku $z$ terapią systemową dochodzi do nasilenia objawów neuropatii zagrażającego życiu.

\section{Opis przypadku}

Pacjent $\mathrm{w}$ wieku 58 lat $\mathrm{z}$ amyloidozą AL kappa nerek, szpiku i serca, zdiagnozowaną w lipcu 2017 roku, po 2 cyklach terapii według schematu VD (bortezomib, deksametazon) w pełnych dawkach podanych w poprzednim ośrodku klinicznym, $z$ polekową łagodną polineuropatią obwodową, zgłosił się do poradni hematologicznej w celu kontynuacji leczenia. W wywiadzie stwierdzono nadciśnienie tętnicze, przewlekłą chorobę nerek kategorii 3a według KDIGO (Kidney Disease Improving Global Outcomes), hiperlipidemię mieszaną oraz lagodny rozrost gruczołu krokowego. Podano 3. cykl VD oraz 1 cykl według schematu CyBorD (cyklofosfamid, bortezomib, deksametazon), osiągając częściową remisję. Ze względu na neuropatię indukowaną chemioterapią bortezomib podawano $\mathrm{w}$ zmniejszonej dawce podskórnie, raz w tygodniu. W leczeniu bólu neuropatycznego stosowano pregabalinę, uzyskując złagodzenie dolegliwości. Pacjenta zakwalifikowano do autologicznego przeszczepienia krwiotwórczych komórek macierzystych (auto-HSCT, autologous hematopoietic stem cell transplantation). W mobilizacji zastosowano czynnik wzrostu kolonii granulocytów (G-CSF, granulocyte colony-stimulating factor) w skojarzeniu $z$ chemioterapią według schematu CTX-VEP (cy- 
klofosfamid, etopozyd). 21 listopada 2017 roku przeprowadzono skuteczną separację komórek macierzystych, uzyskując $34,24 \times 10^{6}$ komórek CD34+/kg mc., a miesiąc później wykonano auto-HSCT. W leczeniu mieloablacyjnym podano melfalan w dawce $200 \mathrm{mg} / \mathrm{m}^{2}$. Toksyczność chemioterapii według Światowej Organizacji Zdrowia (WHO, World Health Organization) wynosiła 0 we wszystkich analizowanych aspektach. Stosowano profilaktyczne leczenie przeciwdrobnoustrojowe (lewofloksacyna, acyklowir, flukonazol). Pacjent był w dość dobrym stanie ogólnym, bez cech neuropatii. Pozostawał on pod opieką poradni poprzeszczepowej do lutego 2018 roku, dalszą obserwację zaplanowano w poradni hematologicznej. W elektroforezie białek surowicy krwi z lutego 2018 roku uwidoczniono słabo wyodrębnioną strefę białka monoklonalnego, czego nie potwierdzono w immunofiksacji, w której uwidoczniono prążki oligoklonalne immunoglobulin IgG lambda-podwójne oraz IgA kappa-podwójne.

W marcu i kwietniu 2018 roku chory był kilkukrotnie hospitalizowany na oddziałach neurologii z powodu zespołu Guillaina-Barré przebiegającego $\mathrm{w}$ postaci osłabienia napięcia mięśniowego kończyn, zaburzenia czucia powierzchniowego i czucia wibracji w dystalnych częściach kończyn dolnych, parestezji w obrębie podudzi $z$ towarzyszącą allodynią oraz parestezji ust i języka. W trakcie hospitalizacji nastąpiło przejściowe pogorszenie stanu neurologicznego pacjenta $-z$ niedowładem obwodowym nerwu VII po lewej stronie, dyzartrią i wiotkim niedowładem czterokończynowym średniego stopnia, bardziej nasilonym w lewych kończynach, bez możliwości samodzielnego poruszania się. W badaniu rezonansu magnetycznego (MRI, magnetic resonance imaging) głowy nie zobrazowano istotnych nieprawidłowości. W badaniu elektroneurograficznym (ENG, electroneurography) wykazano cechy polineuropatii czuciowo-ruchowej typu demielizacyjno-aksonalnego dużego stopnia, bardziej nasilonej w nerwach kończyn dolnych. W elektromiografii (EMG, electromyography) zapis spoczynkowy z przedniego mięśnia piszczelowego nie ujawnił cech denerwacji, Średnie parametry potencjałów jednostek ruchowych pozostawały w normie. Wobec nieskuteczności leczenia preparatami immunoglobuliny ludzkiej zastosowano plazmaferezy, uzyskując stopniową niewielką poprawę. Pacjent został wypisany do domu chodzący $z$ asekuracją laski, $z$ utrzymującymi się parestezjami w obrębie twarzy i niewielkimi zaburzeniami czucia.

W kontrolnej elektroforezie białek surowicy krwi wykonanej w kwietniu 2018 roku uwidocznio-

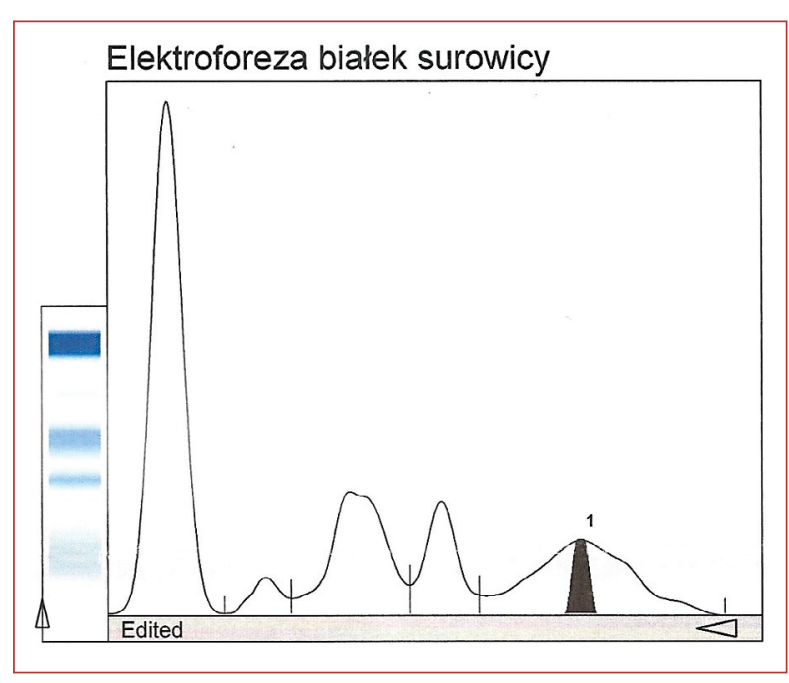

Rycina 1. Elektroforeza białek surowicy krwi wykonana w kwietniu 2018 roku: słabo wyodrębniona strefa białka monoklonalnego

Figure 1. Serum protein electrophoresis, April 2018: slightly separated monoclonal protein zone

no obecność strefy białka monoklonalnego (ryc. 1), co potwierdzono metodą immunofiksacji (słabo wyodrębniona strefa IgG kappa, śladowa strefa IgG lambda; ryc. 2). Stwierdzono progresję amyloidozy. Ze względu na pojawienie się rozsianych zmian skórnych $\mathrm{w}$ przebiegu półpaśca odstąpiono od steroidoterapii. Włączono acyklowir w dawce dostosowanej do stopnia niewydolności nerek.

Po kilku dniach nastąpiło pogorszenie stanu neurologicznego pacjenta $\mathrm{w}$ postaci niedowładu czterokończynowego, niedowładu obwodowego nerwu VII po lewej stronie oraz zaburzeń połykania. W trakcie hospitalizacji na oddziale neurologii zastosowano pulsy steroidowe w dużych dawkach, uzyskując istotną poprawę. Nie wykonano biopsji nerwu obwodowego. Całokształt obrazu klinicznego odniesiono do fluktuującego zespołu Guillaina-Barré, bez podstaw do rozpoznania przewlekłej zapalnej polineuropatii demielinizacyjnej (CIPD, chronic inflammatory demyelinating polyneuropathy).

$\mathrm{W}$ ramach leczenia hematologicznego kontynuowano steroidoterapię, podając deksametazon w monoterapii w dawce początkowej $20 \mathrm{mg} 2$ razy $\mathrm{w}$ tygodniu, stopniowo zmniejszanej. W czerwcu 2018 roku rozpoczęto leczenie według schematu Pom-Dex (pomalidomid, deksametazon), jednak ze względu na obawy pacjenta przed potencjalnymi działaniami niepożądanymi pomalidomidu w postaci polineuropatii zdecydowano o ostawieniu leku. W elektroforezie białek surowicy z sierpnia 2018 roku nie uwidoczniono obecności białka monoklonalnego 


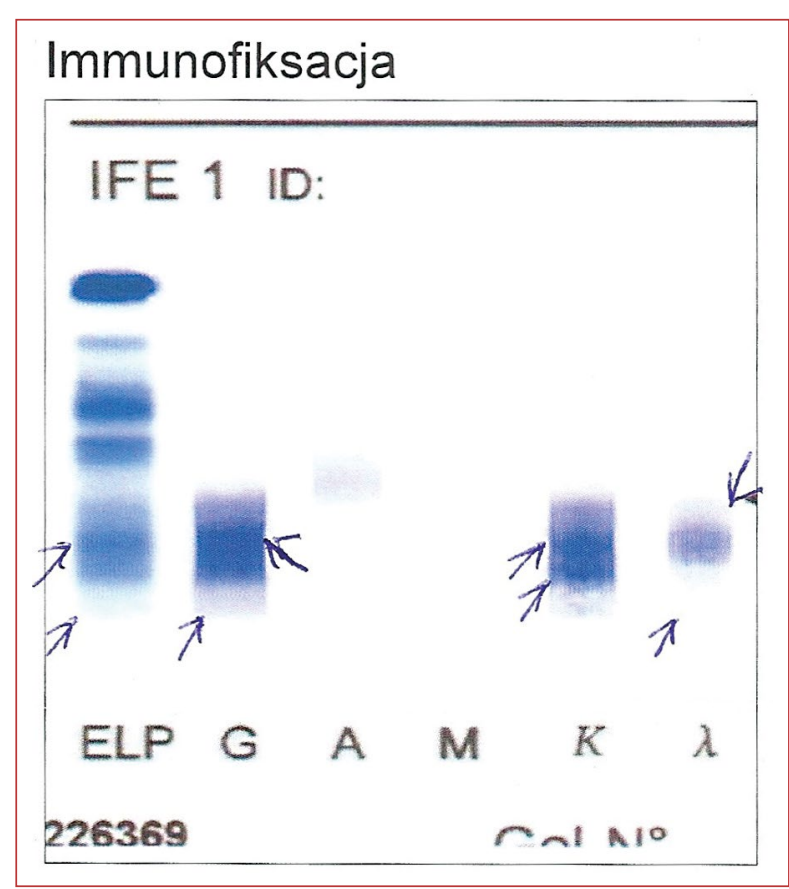

Rycina 2. Immunofiksacja białek surowicy krwi wykonana w kwietniu 2018 roku: obecne słabo wyodrębnione białko monoklonalne lgG kappa oraz śladowa strefa lgG lambda

Figure 2. Serum immunofixation, April 2018: monoclonal protein detected - slightly separated IgG kappa zone and trace of IgG lambda

(ryc. 3), co potwierdzono metodą immunofiksacji (ryc. 4). Pacjent w dobrym stanie ogólnym pozostaje pod stałą opieką poradni hematologicznej.

\section{Dyskusja}

Neuropatia w przebiegu amyloidozy AL przypomina neuropatię cukrzycową [7]. Typowo obejmuje głównie dystalne partie kończyn, symetrycznie. W obrazie klinicznym dominują postępujące zaburzenia czucia, zwłaszcza bólu i temperatury, a w mniejszym stopniu zaburzenia priopriocepcji, ponieważ złogi amyloidu są deponowane głównie w małych włóknach nerwowych $[5,7,8]$. Już w latach 80 . XX wieku wykazano, że rozbieżność między rozwojem neuropatii a niewielkimi anomaliami w badaniu ENG może wynikać $z$ początkowego uszkodzenia niezmielinizowanych włókien $[9,10]$. Neuropatia postępuje stopniowo - obejmuje kolejno włókna sensoryczne, motoryczne i autonomiczne. Dystalne osłabienie napięcia mięśniowego pojawia się w późniejszym okresie, jednak ciężkość neuropatii obwodowej nie koreluje $z$ układowym zaawansowaniem choroby [11]. W badaniu elektro-

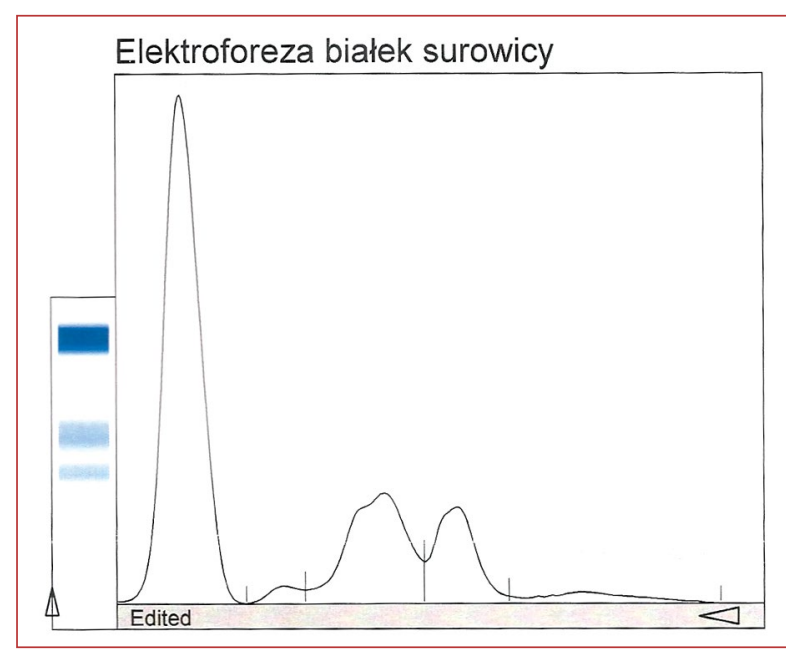

Rycina 3. Elektroforeza białek surowicy krwi wykonana w kwietniu 2018 roku: nie stwierdzono obecności białka monoklonalnego

Figure 3. Serum protein electrophoresis, August 2018: no monoclonal protein detected

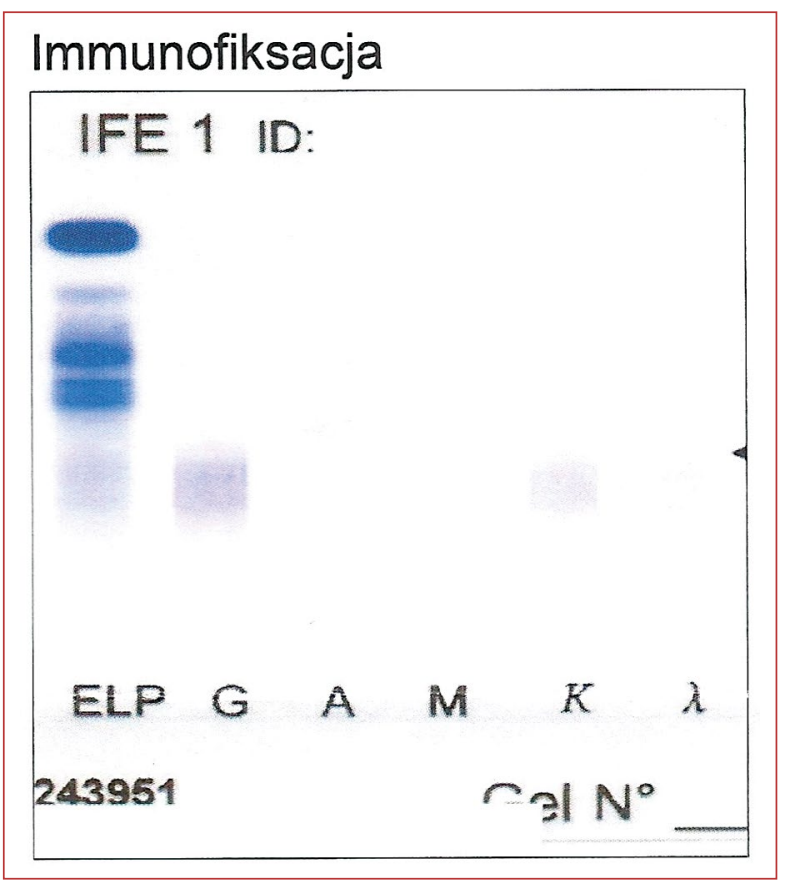

Rycina 4. Immunofiksacja białek surowicy krwi wykonana w sierpniu 2018 roku: nie stwierdzono obecności białka monoklonalnego

Figure 4. Serum immunofixation, August 2018: no monoclonal protein detected

fizjologicznym zwykle obserwuje się cechy neuropatii aksonalnej $z$ obniżoną amplitudą potencjałów nerwowych i wydłużeniem czasu przewodzenia. 
W EMG mogą wystąpić oznaki denerwacji mięśni dystalnych [11].

Vuvic i wsp. [6] zaprezentowali 4 przypadki nietypowych prezentacji klinicznych neuropatii $\mathrm{w}$ przebiegu amyloidozy AL. U jednego $z$ opisywanych chorych rozpoznano CIDP. Pacjent zgłaszał parestezje i bóle stóp, parestezje w obrębie prawej połowy twarzy i rąk, objawy hipotensji ortostatycznej oraz zaburzenia wzwodu. W związku z postępującym niedowładem kończyn nie był w stanie poruszać się samodzielnie. W terapii stosowano dożylne preparaty immunoglobulin, nie uzyskując poprawy. Ze względu na zaburzenia połykania, gastroparezę i cechy kacheksji konieczne było założenie sondy żołądkowej. Stosowano plazmaferezy, ale poprawa była jedynie subiektywna. W badaniu ENG stwierdzono ciężką demielinizacyjną polineuropatię czuciowo-ruchową. Metodą immunofiksacji białek surowicy krwi wykazano obecność białka monoklonalnego IgG lambda. W badaniu histopatologicznym w endoneurium nerwu łydkowego uwidoczniono kongofilne złogi amyloidu. Pacjent zmarł z powodu niewydolności oddechowej jeszcze przed rozpoczęciem chemioterapii.

W literaturze opisano dotychczas jeden przypadek amyloidozy AL przebiegającej w postaci nasilonej postępującej autonomicznej neuropatii przypominającej zespół Guillaina-Barré, obejmującej hipotensję ortostatyczną, gastroparezę i dysfunkcję pęcherza moczowego [12]. Ponadto $\mathrm{w}$ badaniu neurologicznym stwierdzono zmniejszone napięcie mięśniowe, zaburzenia czucia oraz osłabione odruchy głębokie, bardziej zaznaczone w kończynach dolnych. W EMG stwierdzono cechy neuropatii obwodowej typu aksonalnego. W tym przypadku rozpoznania amyloidozy dokonano na podstawie badania pośmiertnego.

$\mathrm{W}$ badaniach naukowych przeprowadzonych jeszcze w XX wieku wykazano, że przeżycia całkowite (OS, overall survival) pacjentów ze zdiagnozowaną amyloidozą AL, z izolowaną neuropatią obwodową, są dłuższe niż u pozostałych chorych $[4,13,14]$. Ponadto obecnie - dzięki zastosowaniu nowych leków w terapii amyloidozy AL — możliwe jest uzyskanie stopniowej poprawy neurologicznej w ciągu kilku lat. W wielu przypadkach jednak uszkodzenie włókien nerwowych przez złogi amyloidu pozostaje nieodwracalne [5, 7, 8]. Opóźnienie diagnozy i rozpoczęcia leczenia systemowego uniemożliwia uzyskanie pełnego efektu terapeutycznego [5, 9].

Dodatkową trudnością w postępowaniu $z$ chorymi cierpiącymi na neuropatię w przebiegu amyloidozy AL są działania niepożądane nowych leków, obejmujące także neuropatię. W terapii układowej amyloidozy AL opartej na nowych lekach $z$ grupy PI i IMiD neuropatię obserwuje się najczęściej w przypadku stosowania bortezomibu i talidomidu $[1,15]$. Neuropatia indukowana chemioterapią zwykle dotyczy symetrycznie dystalnych części kończyn, $z$ pewnymi różnicami zależnie od schematu terapii [16]. Neuropatia indukowana talidomidem zależy od skumulowanej dawki leku i często jest nieodwracalna. Może wystąpić nawet po zakończeniu leczenia [16, 17]. Neuropatia indukowana bortezomibem zależy natomiast od wielkości dawki jednorazowej, częstości oraz drogi podawania i w większości przypadków pozostaje odwracalna [16, 17]. Uznanymi czynnikami ryzyka rozwoju neuropatii są: cukrzyca, nadwaga, nadużywanie alkoholu, wcześniejsze stosowanie leków cytostatycznych (winkrystyna, cisplatyna), niedobory witaminowe (witamina D) [1].

Kluczowe jest podjęcie działań zapobiegających wystąpieniu polineuropatii obwodowej indukowanej chemioterapią w celu utrzymania dobrej jakości życia pacjenta i umożliwienia realizacji planowego leczenia przyczynowego. Według zaleceń Polskiej Grupy Szpiczakowej zmniejszenie dawki talidomidu i bortezomibu stanowi ,złoty standard” postępowania prewencyjnego. Złagodzenie polineuropatii można osiągnąć również, podając bortezomib podskórnie, dawkując lek raz w tygodniu lub stosując deksametazon $\mathrm{w}$ dniu podania PI oraz dzień po jego podaniu. Istotne jest także leczenie wspomagające, którego podstawą są koanalgetyki - pochodne kwasu gamma-aminoomasłowego (gabapentyna, pregabalina), leki przeciwdepresyjne z grupy inhibitorów wychwytu zwrotnego serotoniny i noradrenaliny (duloksetyna) czy trójpierścieniowych leków przeciwdepresyjnych (amitryptylina).

W opisywanym przypadku od początku prowadzenia pacjenta $\mathrm{w}$ poradni hematologicznej obserwowano neuropatię indukowaną bortezomibem, której objawy łagodzono pregabaliną. Po przeprowadzeniu auto-HSCT dolegliwości uległy istotnemu złagodzeniu. $\mathrm{W}$ momencie nasilenia zaburzeń neurologicznych o charakterze zespołu Guillaina-Barré chory nie reagował na standardowe leczenie preparatami ludzkiej immunoglobuliny i plazmaferez. Ciężkie objawy demielinizacji aksonalnej poprzedziły progresję amyloidozy, a ich stopniowe wygaszenie zaobserwowano dopiero po włączeniu pulsów steroidowych. W obawie przed neuropatią indukowaną pomalidomidem, występującą według charakterystyki produktu leczniczego z częstością około $12 \%$, pacjent zadecydował o zaprzestaniu stosowania leku. Obecnie przyjmuje 
deksametazon w monoterapii, pozostając do tej pory bez progresji choroby podstawowej i nowych zaburzeń neurologicznych. Ze względu na brak reakcji na standardowe leczenie zespołu Guillaina-Barré i obserwowaną zadowalającą poprawę stanu pacjenta po zastosowaniu steroidów w dużych dawkach wydaje się prawdopodobne, że nasilone objawy neurologiczne stanowiły zwiastun postępu amyloidozy, a włączenie leczenia przyczynowego pozwoliło opanować postępujące objawy ze strony układu nerwowego.

\section{Podsumowanie}

W kontekście przytoczonej literatury neuropatia związana $z$ amyloidozą układową AL stanowi poważne wyzwanie diagnostyczne ze względu na możliwe różnorodne prezentacje kliniczne. Może wyprzedzać rozpoznanie amyloidozy, jak również zwiastować progresję choroby. Kluczowe jest włączenie odpowiedniego leczenia systemowego zapobiegającego postępowi zaburzeń neurologicznych i - w części przypadków - umożliwiającego uzyskanie poprawy w zakresie niektórych funkcji.

\section{Piśmiennictwo}

1. Dmoszyńska A, Usnarska-Zubkiewicz L, Walewski J, et al. Zalecenia Polskiej Grupy Szpiczakowej dotyczące rozpoznawania i leczenia szpiczaka plazmocytowego oraz innych dyskrazji plazmocytowych na rok 2017. Acta Haematol Pol. 2017; 48(2): 55-103, doi: 10.1016/j.achaem.2017.05.003.

2. Antoine JC, Camdessanché JP. Paraneoplastic neuropathies. Curr Opin Neurol. 2017; 30(5): 513-520, doi: 10.1097/ /WCO.0000000000000475, indexed in Pubmed: 28682959.

3. Duston MA, Skinner M, Anderson J, et al. Peripheral neuropathy as an early marker of AL amyloidosis. Arch Intern Med. 1989; 149(2): 358-360, indexed in Pubmed: 2537065.

4. Kyle RA, Greipp PR. Amyloidosis (AL). Clinical and laboratory features in 229 cases. Mayo Clin Proc. 1983; 58(10): 665-683, indexed in Pubmed: 6353084.

5. Rajkumar SV, Gertz MA, Kyle RA. Prognosis of patients with primary systemic amyloidosis who present with dominant neu- ropathy. Am J Med. 1998; 104(3): 232-237, indexed in Pubmed: 9552085.

6. Vucic S, Chong PS, Cros D. Atypical presentations of primary amyloid neuropathy. Muscle Nerve. 2003; 28(6): 696-702, doi: 10.1002/mus.10505, indexed in Pubmed: 14639583.

7. Gertz MA. Immunoglobulin light chain amyloidosis: 2016 update on diagnosis, prognosis, and treatment. Am J Hematol. 2016; 91(9): 947-956, doi: 10.1002/ajh.24433, indexed in Pubmed: 27527836.

8. Simmons Z, Specht CS. The neuromuscular manifestations of amyloidosis. J Clin Neuromuscul Dis. 2010; 11(3): 145-157, doi: 10.1097/CND.0b013e3181d05994, indexed in Pubmed: 20215989.

9. Kelly JJ, Kyle RA, O'Brien PC, et al. The natural history of peripheral neuropathy in primary systemic amyloidosis. Ann Neurol. 1979; 6(1): 1-7, doi: 10.1002/ana.410060102, indexed in Pubmed: 228587.

10. Adams D, Lozeron P, Lacroix C. Amyloid neuropathies. Curr Opin Neurol. 2012; 25(5): 564-572, doi: 10.1097/ /WCO.0b013e328357bdf6, indexed in Pubmed: 22941262.

11. Barsottini OG, Arantes A, Sigulem D, et al. Axoval neuropathy as initial manifestation of primary amyloidosis: report of a case submitted to bone marrow transplantation. Arq Neuropsiquiatr. 2004; 62(3A): 725-729, doi:/S0004-282X2004000400030, indexed in Pubmed: 15334239.

12. Lingenfelser T, Linke RP, Dette $\mathrm{S}$, et al. AL amyloidosis mimicking a preferentially autonomic chronic Guillain-Barré syndrome. Clin Investig. 1992; 70(2): 159-162, indexed in Pubmed: 1600343.

13. Kyle RA, Dyck PJ. Amyloidosis and neuropathy. In: Griffin JJ, Low PA, Podusto J. ed. Peripheral neuropathy. WB Saunders Company, Philadelphia 1993: 1294-310.

14. Gertz MA, Kyle RA. Primary systemic amyloidosis - a diagnostic primer. Mayo Clin Proc. 1989; 64(12): 1505-1519, indexed in Pubmed: 2513459.

15. Terpos E, Kleber M, Engelhardt M, et al. European Myeloma Network. European Myeloma Network guidelines for the management of multiple myeloma-related complications. Haematologica. 2015; 100(10): 1254-1266, doi: 10.3324/haematol.2014.117176, indexed in Pubmed: 26432383.

16. Delforge M, Bladé J, Dimopoulos MA, et al. Treatment-related peripheral neuropathy in multiple myeloma: the challenge continues. Lancet Oncol. 2010; 11(11): 1086-1095, doi: 10.1016/ /S1470-2045(10)70068-1, indexed in Pubmed: 20932799.

17. Richardson PG, Delforge M, Beksac M, et al. Management of treatment-emergent peripheral neuropathy in multiple myeloma. Leukemia. 2012; 26(4): 595-608, doi: 10.1038/leu.2011.346, indexed in Pubmed: 22193964. 